\title{
Expression and Function of CCL17 in Atopic Dermatitis
}

\author{
Susanne Stutte ${ }^{1}$, Nancy Gerbitzki ${ }^{2}$, Natalija Novak ${ }^{3}$ and Irmgard Förster ${ }^{2}$ \\ ${ }^{1}$ Department of Microbiology and Immunobiology \\ Division of Immunology, Harvard Medical School, Boston \\ ${ }^{2}$ Molecular Immunology, IUF - Leibniz Research Institute \\ for Environmental Medicine, Düsseldorf \\ ${ }^{3}$ Department of Dermatology and Allergy \\ University of Bonn Medical Center, Bonn \\ ${ }^{1}$ USA \\ 2,3 Germany
}

\section{Introduction}

Chemokines are a superfamily of potent leukocyte chemoattractant cytokines with a molecular weight of 8-12 kDa. Historically, many chemokines had more than one name until the 1999 Keystone Symposium on Chemokines, when a new nomenclature was introduced (Zlotnik \& Yoshie, 2000). Chemokines have been subdivided into four subfamilies on the basis of the position of either one or two cysteine residues located near the N-terminus of the protein and an L (ligand) was added (CXCL, CCL, CL and CXXXCL) to designate all chemokines as ligands of their respective receptors $(\mathrm{R})$. The chemokine network comprises about 50 chemokines, as well as 20 classical (10 CCRs, 7 CXCRs, two XCR and a single $\mathrm{CX} 3 \mathrm{CR}$ ) and 3 atypical chemokine receptors (Duffy antigen receptor for chemokines = DARC, CC-X-chemokine receptor (CCX-CKR), and the D6 molecule) (Cyster, 2005; Comerford \& McColl, 2011; Hansell \& Nibbs, 2007; Ransohoff, 2009; Sallusto \& Baggiolini, 2008). Many ligands bind multiple receptors, although each of them bind in a slightly different way, thereby inducing distinct downstream responses. The timing and venue of specific ligand-receptor interactions determines the nature of various biological processes. Although their best known function is the regulation of leukocyte migration, chemokines also enhance cell adhesion or costimulation, and stimulate myelopoiesis, tumor growth or angiogenesis (Ransohoff, 2009; Sallusto \& Baggiolini, 2008; Viola \& Luster, 2008). In addition, chemokines participate in the organization of the microenvironmental architecture of primary and secondary lymphoid organs during physiological and pathological conditions (Cyster, 2005). Importantly, a defined subset of chemokines and their receptors drive certain inflammatory immune responses to protect the body against microbial and environmental pathogens. Dysregulation of such chemokines may contribute to the pathogenesis of inflammatory diseases, like acute respiratory distress syndrome, multiple sclerosis, inflammatory bowel diseases, atherosclerosis, or rheumatoid arthritis (Charo \& Ransohoff, 2006). Furthermore, chemokines produced in barrier organs are known to 
substantially contribute to the pathogenesis of atopic diseases, like asthma, rhinitis and atopic dermatitis (D'Ambrosio, 2005; Homey et al., 2006; Pease, 2011).

\subsection{Chemokine signaling}

Chemokine receptors are pertussis toxin-sensitive heterotrimeric ( $\alpha \beta \gamma)$ G-protein coupled receptors (GPCR) with seven helical membrane-spanning regions connected by extramembranous loops. Ligand binding induces a series of intracellular signalling pathways, leading to changes in actin cytoskeleton, activation of integrins, cell migration and alterations of the cellular activation status. For detailed information on chemokine receptor signaling pathways we refer the reader to other review articles covering this topic specifically (Randolph et al., 2008; Thelen \& Stein, 2008; Wu, 2005). Briefly, chemokine ligand binding induces activation of the $G$ proteins associated with the chemokine receptor causing the dissociation of Ga-GTP from the receptor and from the G $\beta \gamma$ heterodimer. Whereas the $G \alpha$ subunit inhibits adenylyl cyclases, the $G \beta \gamma$ subunit is able to activate several effectors, including phosphatidylinositol-3-OH-kinase (PI3K) and members of the phospholipase $\mathrm{C}$ family. In addition, chemokine receptor signaling leads to activation of small GTPases of the Rho and Ras families.

\subsection{Regulation of chemokine receptor expression}

Many chemokine receptor genes are constitutively expressed and their cell surface expression ranges from as few as around 1000/cell in the case of CXCR4 to around 40,000/cell in the case of CXCR2 on neutrophils (Holmes et al., 1991; Loetscher et al., 1994). Chemokine receptor expression can be regulated by two major mechanisms: enhanced/reduced gene expression and/or desensitization. Altered gene expression of chemokine receptors is evident in naïve $\mathrm{T}$ lymphocytes expressing high levels of homeostatic receptors that mediate circulation through secondary lymphoid organs. Once activated, homeostatic receptors are down-regulated, and inflammatory chemokine receptors are up-regulated on effector cells ( Ebert \& McColl, 2002; Sallusto et al., 1998a). This allows effector cells to migrate into tissues where the ligands for the inflammatory receptors are being expressed. This mechanism also regulates DC trafficking into tissues, within tissues and from tissues into draining LN. Chemokine receptors may also undergo transient homologous or heterologous desensitization (Aragay et al., 1998; Mashikian et al., 1999). Binding of the ligand leads to phosphorylation-dependent internalization of the receptor and abolishes further chemokine stimulation. This is called homologous desensitization. In contrast, heterologous desensitization happens when molecules other than those that bind directly can desensitize chemokine receptors, for example by utilization of common intracellular signalling pathways, or by alterations in the phosphorylation status of the receptor.

\section{Chemokine and chemokine receptor expression in AD}

$\mathrm{AD}$ represents a chronic relapsing skin disease induced by epidermal barrier dysfunctions, sensitization to environmental allergens, microbial stimulation, and genetic predisposition (Bieber, 2008). The lesional skin contains many signs of leukocytic inflammation, resulting from enhanced production of proinflammatory cytokines and chemokines (Gros et al., 2009; Homey et al., 2006; Pastore et al., 2004). One of the initial events in the pathogenesis of AD is 
a disturbance of the epidermal barrier and subsequent activation of keratinocytes by penetrating microbial and environmental pathogens or allergens. Release of proinflammatory cytokines, such as thymic stromal lymphopoetin (TSLP), IL-25 and IL-33 initially leads to the activation and/or attraction of innate immune cells, including cutaneous DC, and induction of a Th2-biased immune response (Carmi-Levy et al., 2011). During this phase a panel of homeostatic and inflammatory chemokines are upregulated in the affected skin areas, promoting the attraction of pro-allergic effector cells, like mast cells, eosinophils, inflammatory DC and cutaneous lymphocyte antigen (CLA) ${ }^{+}$CCR4 ${ }^{+}$skinhoming Th cells. Chemokines associated with an AD phenotype comprise CCL1, CCL2, CCL3, CCL5, CCL11, CCL13, CCL17, CCL18, CCL20, CCL22, CCL26, CCL27 and CX3CL1, and serum levels of CCL11, CCL17, CCL22, CCL26, CCL27 and CX3CL1 correlate with disease activity (Homey et al., 2006).

CCL1, CCL11 and CCL26 have been shown to interact with CCR8 and CCR3 on endothelial cells in $\mathrm{AD}$, thereby inducing angiogenesis and tissue remodelling (Owczarek et al., 2010; Salcedo et al., 2001; Yawalkar et al., 1999). CCL1-CCR8 interactions also lead to recruitment of $\mathrm{T}$ cells and LC-like DC to the inflamed skin (Gombert et al., 2005), and have been associated with emigration of LC to the draining LN (Qu et al., 2004).

CCL27 is already expressed under homeostatic conditions and is further induced under inflammatory conditions in epidermal keratinocytes. In addition, CCL27 binds to the extracellular matrix and is displayed on endothelial cells in inflamed skin (Homey et al., 2002). CCR10, the receptor of CCL27, is preferentially expressed by CLA+CD4+ ${ }^{+}$or CD8 ${ }^{+}$ memory $T$ cells (Hudak et al., 2002). Neutralization of CCL27 significantly inhibited inflammatory skin responses in mouse models that mimic allergic contact dermatitis and AD (Homey et al., 2002; Hudak et al., 2002). In addition to CCR10, the skin-homing CLA ${ }^{+}$ memory T cells express CCR4 on their cell surface. As further discussed below, CCR4 and CCR10 ligands cooperate in the recruitment of memory $\mathrm{T}$ cells to sites of skin inflammation (Mirshahpanah et al., 2008; Reiss et al., 2001).

The human chemokine CCL18 is one of the most highly expressed chemokines produced by DC in lesional skin of AD patients but not in psoriasis (Fujita et al., 2011; Gros et al., 2009; Pivarcsi et al., 2004). Pivarcsi et al. showed that allergen exposure, as well as staphylococcal products induced its expression in vitro and in vivo. Although the receptor of CCL18 is still unknown, this chemokine has been shown to attract CLA+ memory T cells (Günther et al., 2005).

\section{Function and expression of CCL17}

\subsection{Classification of CCL17 as an inflammatory chemokine}

The $\beta$-chemokine CCL17 formerly known as Thymus- and Activation Regulated Chemokine (TARC), was first identified as a T cell chemoattractant by the group of O. Yoshie in human thymus, and phytohemagglutin stimulated peripheral blood mononuclear cells (Imai et al., 1996). Later on, the murine homologue was identified in murine bone marrow derived DC (BMDC) (Lieberam \& Förster, 1999) and anti-CD40 stimulated splenic B cells (Schaniel et al., 1999). CCL17 shares the highest homology (32\% amino acid identity) with CCL22 (macrophage-derived chemokine (MDC) and both chemokines signal through CCR4. CCR4 is expressed on T helper (Th)-1 and Th2 cells (D'Ambrosio et al., 1998; Sallusto et al., 1998a) but also on Th17 cells (Acosta-Rodriguez et al., 2007; Annunziato et al., 2007), CD8 ${ }^{+} \mathrm{T}$ cells (Kondo \& Takiguchi, 2009; Semmling et al., 2010), regulatory T cells (Treg) (Iellem et al., 
2001), natural killer T (NKT) cells (Kim et al., 2002), NK cells (Inngjerdingen et al., 2000), platelets (Clemetson et al., 2000), eosinophils and monocytes (Bochner et al., 1999). Despite the broad expression pattern of CCR4, CCL17 has been mainly associated with Th2 type immune reactions and is implicated in the pathogenesis of several Th2-mediated diseases like atopic dermatitis (Sallusto et al., 1998a; Imai et al., 1999; Saeki \& Tamaki, 2006). Besides attraction of Th2 cells, however, CCL17 may also induce chemotaxis of memory T cells, Treg and Th1 cells (Iellem et al., 2001; Lieberam \& Förster, 1999). In addition, other CCR4expressing cell types like CD8 ${ }^{+} \mathrm{T}$ cells, NK cells, basophils, eosinophils and DC may also respond to CCL17. As an inflammatory chemokine CCL17 is strongly upregulated in immature DC after stimulation with TLR ligands (Alferink et al., 2003; Lieberam \& Förster, 1999). In addition, it can be upregulated following stimulation with various proinflammatory cytokines, as detailed below.

\subsubsection{Transcriptional regulation of CCL17 expression}

Whereas most CC chemokine genes are clustered on human chromosome 17 (mouse chromosome 11), ccl17 is located downstream of ccl22 and cx3cl1 on the human chromosome 16q13 and mouse chromosome 8q (Hiroyama et al., 2001). The promoter region of $c c l 17$ contains several transcriptional regulation sites, like signal transducer and

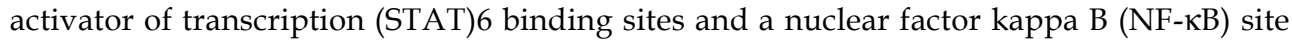
(Liddiard et al., 2006; Liu et al., 2007; Monick et al., 2007; Nakayama et al., 2004; Wirnsberger et al., 2006). Expression of CCL17 is induced by the Th2 cytokines interleukin (IL)-4 and IL-13 via STAT6, and NF- $\mathrm{KB}$ activation occurs in response to TLR signaling. In the case of CCL17 expression, both pathways appear to act synergistically (Monick et al., 2007). In addition, other cytokines, like tumor necrosis factor (TNF)- $\alpha$, granulocyte/macrophage colony stimulating factor (GM-CSF), and TSLP have also been shown to upregulate CCL17 expression (Heijink et al., 2007; Imai et al., 1999; Liu et al., 2007; Soumelis et al., 2002; Wirnsberger et al., 2006; Xiao et al., 2003). TSLP is an IL-7-like cytokine produced mainly by keratinocytes in an inflammatory environment. TSLP induces maturation of myeloid DC, which in turn produce CCL17 and CCL22. In contrast, Interferon gamma (IFN- $\gamma$ ) has been shown to act as a counter regulator of CCL17 production (Fujita et al., 2005; Xiao et al., 2003), although this cytokine enhances CCL17 expression in conjunction with TNF- $\alpha$ in the HaCaT keratinocyte cell line (Vestergaard et al., 2001). A unique feature of murine CCL17 is that additionally to its own promoter, transcription in brain and kidney may be initiated from the promoter of the closely linked CX3CL1 (fractalkine) gene, resulting in expression of a protein containing the CX3CL1 signal sequence and the CCL17 coding region (Hiroyama et al., 2001).

\subsection{Cell-type specificity of CCL17 expression in human and mouse}

In mice, mature $\mathrm{CD} 11 \mathrm{c}^{+} \mathrm{CD} 8 \mathrm{CD} 11 \mathrm{~b}^{+}$myeloid $\mathrm{DC}$ represent the predominant source of CCL17 production. Under steady state conditions, CCL17 is highly expressed in DC of the thymus, peripheral and mesenteric LN, small intestine, colon, and lung (Alferink et al., 2003). Apart from the thymus, all of these organs are associated with environmental barriers. The expression pattern of CCL17 emphasizes its importance in mediating the attraction of immune cells to sites, which are frequently exposed to environmental pathogens or allergens. Interestingly, CCL17 expression is normally not found in the spleen, even after systemic LPS challenge (Alferink et al., 2003). The only agent identified so far, 
which is able to strongly induce CCL17 in splenic DC, is the synthetic glycolipid $\alpha$-galactosylceramide, a well known CD1d-dependent inducer of NKT cell activation (Semmling et al., 2010). After licensing by activated NKT cells, cross-priming CD8 ${ }^{+}$DC produce CCL17 and attract naïve cytotoxic T cells expressing CCR4. Based on the analysis of CCL17/EGFP reporter mice, expression of CCL17 is fairly restricted to DC and has not been observed in keratinocytes, B cells, endothelial or epithelial cells. Dermal DC (dDC) and LC in normal, untreated skin of mice are also CCL17-negative but turn on CCL17 expression following irritation or injury of the skin (Stutte et al., 2010).

Although healthy human skin is devoid of CCL17 expression as well, human keratinocytes were shown to express CCL17 in inflamed skin, such as lesional skin of AD patients (Kakinuma et al., 2001; Vestergaard et al., 2000). In vitro, CCL17 expression is also found constitutively in HaCaT cells and is further inducible by cytokine stimulation (Vestergaard et al., 2001), whereas normal human keratinocytes did not express CCL17 protein in vitro, even after cytokine stimulation (Tsuda et al., 2003; Saeki \& Tamaki, 2006). In contrast, human LC, Inflammatory Dendritic Epidermal Cells (IDEC) and dDC strongly express CCL17 (and CCL22) in inflammatory environments, particularly in lesional skin of AD patients, as do LPS stimulated human monocyte-derived DC (D'Ambrosio et al., 2002; Fujita et al., 2011; Kang et al., 2010; Soumelis et al., 2002). In addition, non-haematopoietic cells, such as bronchial epithelial cells, endothelial cells, fibroblasts, as well as smooth muscle cells can be a source of inducible CCL17 in humans (D'Ambrosio et al., 2002; Faffe et al., 2003; Sekiya et al., 2003; Yu et al., 2002). Taken together, under inflammatory conditions CCL17 appears much more widely expressed in different cell-types in human as opposed to mice, where CCL17 expression is quite restricted to DC subsets. However, detection of CCL17 protein expression by immunohistology as it has frequently been performed in human studies, may also pick up CCL17 that is passively absorbed to the cell membrane, for example by adhesion to surface glycosaminoglycans, and may not necessarily reflect transcription of the ccl17 gene in the same cell-type.

\subsection{Clearance of CCL17}

CCL17 interacts with two chemokine decoy receptors, the Duffy antigen (DARC) and the D6 receptor. The Duffy antigen is found on red blood cells and binds both CC and CXC chemokines. In contrast, D6 is expressed on lymphatic endothelial cells in skin, gut and lung and interacts with inflammatory CC chemokines only. Although D6 is structurally similar to other chemokine receptors, it is most homologous to CCR4 and CCR5. Ligand binding induces rapid internalization of the ligand-receptor complexes, which facilitates regulation of inflammatory immune responses and enables the final return to homeostatic levels. Interestingly, the homeostatic chemokines CCL19 and CCL21 cannot efficiently bind D6 (Bonecchi et al., 2004). Instead, CCL19, CCL21 and CCL25 are able to bind with high affinity to another hepta-helical surface protein, termed CCX-CKR, which also acts as a chemokine scavenger (Comerford et al., 2006; Gosling et al., 2000).

\section{CCL17 in atopic dermatitis}

$\mathrm{AD}$ is one of the most frequent chronic inflammatory skin diseases in children and adults and is characterized by pruritic skin lesions in typical body areas such as the flexural folds on dry skin (Bieber, 2008). Various exogenous and endogenous factors, including allergens 
and microbial antigens have been identified as triggers of acute flare ups of the disease as well as risk factors for severe persistent courses (Novak \& Simon, 2011). In addition, a multitude of genetic modifications impact on disease manifestation, including a partially genetically predetermined disturbed skin barrier (Barnes, 2010; O'Regan \& Irvine, 2010). Not only lesional AD skin, but also clinically non-lesional skin of AD patients displays multiple histologic as well as immunologic differences as compared to the skin of healthy individuals (Suárez-Fariñas et al., 2011). One of those differences is the expression of the high affinity receptor for IgE (FceRI) on the surface of skin DC. While FceRI ${ }^{+}$LC are present in nonlesional $\mathrm{AD}$ skin, development of skin lesions goes along with the infiltration of the epidermis by another $\mathrm{CD}^{+} \mathrm{a}^{+}$myeloid DC subpopulation, highly expressing FceRI but negative for Birbeck granules and respective Langerin expression, which have been characterized as IDEC (Novak \& Bieber, 2005; Wollenberg et al., 1995).

As mentioned above, a large number of chemokines have been found to be upregulated in lesional skin and serum of AD patients and several chemokine-chemokine receptor pairs have been linked to the pathogenesis of AD, in particular CCL1-CCR8, CCL17/CCL22CCR4, CCL18, CCL20-CCR6, and CCL27-CCR10 (Gros et al., 2009; Homey et al., 2006; Pastore et al., 2004; Pease \& Williams, 2006). In AD, chemokines regulate the emigration of DC to the draining LN as well as the attraction of activated T cells, eosinophils, basophils and mast cells to the site of inflammation. In the following, we will focus on the role of the two CCR4 ligands CCL17 (TARC) and CCL22 (MDC) as biomarkers of disease severity in $\mathrm{AD}$, and the functional influence of these chemokines on the pathogenesis of AD.

\subsection{CCL17 as a biomarker for disease severity in AD}

The first indication that CCL17 is upregulated in lesional AD skin came from the analysis of inflamed skin from $\mathrm{NC} / \mathrm{Nga}$ mice, which spontaneously develop AD-like skin lesions (Vestergaard et al., 1999). Soon after that, enhanced frequencies of $\mathrm{CLA}^{+} \mathrm{CCR} 4^{+} \mathrm{T}$ lymphocytes were detected in the blood of $\mathrm{AD}$ patients, as well as a localized upregulation of CCL17 in the basal layers of the epidermis in lesional skin, presumably in keratinocytes (Vestergaard et al., 2000). Later on, numerous clinical studies demonstrated that CCL17 levels in serum of AD patients and the presence of CCL17 in lesional skin correlate with disease activity (for review see (Saeki \& Tamaki, 2006)). As shown recently, expression of both, CCL17 as well as CCL22 is higher in LC and IDEC of patients with AD as compared to LC in healthy skin or epidermal DC isolated from the epidermis of patients with other chronic inflammatory skin diseases such as psoriasis (Fujita et al., 2011). Moreover, even dermal DC in AD express higher levels of CCL17 and CCL22. The selective upregulation of those chemokines in DC in AD skin further supports the concept of CCL17 and CCL22 being crucial for the recruitment of Th2 cells, which predominate in particular in the acute phase of the disease (Grewe et al., 1998). Sequential biopsies taken from the same individuals during atopy patch testing revealed more detailed insights into the kinetics and nature of chemokine upregulation in the skin during early and late phases of eczema development. For this diagnostic test, allergens are applied to the skin occlusively for 24 hours and eczema develops within 24-72 hours in the region of allergen application in sensitized individuals (Darsow et al., 1996). Expression of CCL17 and CCL22 is among other chemokines rapidly upregulated on the mRNA level already 24 hours later and increases further during the following 48 hours. In parallel, the number of inflammatory DC subtypes in the epidermis as well as $\mathrm{T}$ cells in the dermis increases 
(Gros et al., 2009). The intensity of chemokine upregulation as well as the pattern of chemokines induced seem to be decisive for the development of eczematous skin lesions. Consequently, it is very likely that improvement of the skin lesions will occur in parallel with the reduction in amount of particular chemokines in the skin, leading to the discontinuation of the recruitment of inflammatory cell subtypes. In line with this, treatment of AD patients by immunotherapy (Bussmann et al., 2007; Kwon et al., 2010), or culture of PBMC with antihistamines (Furukawa et al., 2004; Shoji et al., 2011) leads to a significant reduction of CCL17 expression. Recently, immunofluorescence detection of CCL17 in the skin of AD patients showed that CCL17 expression levels in the stratum corneum correlate with disease activity as well (Morita et al., 2010). As for CCL17, similar findings have been obtained for the other CCR4 ligand CCL22 (Goebeler et al., 2001; Shimada et al., 2004), although CCL17 or CCL22 appear to be expressed by different cell types in the skin as determined by immunohistology (Vestergaard et al., 1999). Whereas CCL17 expression was mostly located to the basal layers of the epidermis, CCL22 expression was predominantly found in dermal cells. In addition, Hashimoto et al. described CCL22 to be more strongly upregulated in human monocyte-derived DC isolated from AD patients than CCL17, when compared to expression levels in healthy controls (Hashimoto et al., 2006).

Interestingly, the keratinocyte-derived cytokine TSLP, which is strongly upregulated in the epidermis of AD lesional skin specifically induces CCL17 and CCL22 expression in human peripheral blood CD11c $\mathrm{c}^{+}$DC (Soumelis et al., 2002) as well as human epidermal LC (Ebner et al., 2007). TSLP expression levels in the skin also correlated with enhanced migratory activity of LC (Guttman-Yassky et al., 2007; Soumelis et al., 2002). A possible link between skin barrier dysfunction and CCL17 was recently reported by Nakahigashi et al., who showed that CCL17 was able to induce aquaporin-3 in human keratinocytes, which in turn promoted keratinocyte proliferation and disturbed barrier function (Nakahigashi et al., 2010).

Whereas elevated levels of CCL17 and CCL22 have also been observed in allergic contact dermatitis (Bäumer et al., 2004; Goebeler et al., 2001; Kamsteeg et al., 2010; Martín et al., 2002;), CCL17/CCL22 expression is not significantly increased in Psoriasis vulgaris (Gros et al., 2009; Kakinuma et al., 2002; Kamsteeg et al., 2010; Saeki \& Tamaki, 2006; Uchida et al., 2002). This correlates with the fact that psoriasis is a Th1 dominated disease, whereas Th2type cytokines and chemokines dominate the initial phase of AD, with a shift to Th1-type cytokines in the chronic phase (Grewe et al., 1998; Fujita et al., 2011). In psoriasis, Th17 cells act together with Th1 cells in disease pathogenesis (Lowes et al., 2008; Nograles et al., 2009). The Th17 $\mathrm{T}$ cell subset has also been detected at enhanced frequencies in lesional skin and peripheral blood of AD patients, mainly in the acute phase of the disease (Koga et al., 2008; Toda et al., 2003). In addition, IL-17 was found to be produced by T cells infiltrating the skin of filaggrin-deficient mice (Oyoshi et al., 2009). In another study, however, T22 cells, which produce IL-22 but not IL-17, rather than Th17 cells were reported to be especially increased in $\mathrm{AD}$ as opposed to psoriasis (Nograles et al., 2009). In line with this, Hayashida et al. reported that the presence of Th17 cells negatively correlated with CCL17 and IgE levels in AD patients, whereas serum IL-22 levels positively correlated with those of CCL17 (Hayashida et al., 2011a; 2011b). Whereas IL-17 has proinflammatory and anti-microbial effects, IL-22 inhibits terminal differentiation of keratinocytes and enhances epidermal hyperplasia (Nograles et al., 2008). 


\subsection{Pathogenic role of CCL17 in mouse models of AD}

To study the mechanism of action of CCL17 in the pathogenesis of AD several mouse models have been employed. In general, mouse models of $\mathrm{AD}$ can be classified into spontaneous or intentional genetic mutants, and AD models induced by chronic treatment of wild-type or genetically modified mouse strains with epicutaneous allergens (for review see (Jin et al., 2009a)). There are two major spontaneous mouse models of AD, the NC/Nga (Matsuda et al., 1997) and the flaky tail mice (Fallon et al., 2009; Moniaga et al., 2010). In NC/Nga mice, dermatitis occurs only when the animals are kept under conventional breeding conditions but not under specified pathogen free conditions (Vestergaard et al., 1999), indicating that both genetic and environmental factors contribute to disease pathogenesis. In this mouse strain upregulation of CCL17 and CCL22 in lesional skin was first described (Vestergaard et al., 1999). Flaky tail mice harbor a single base pair nonsense mutation in the filaggrin gene, mimicking similar mutations found in AD patients (Fallon et al., 2009; Moniaga et al., 2010). Filaggrin deficiency results in an outside-to-inside skin barrier dysfunction and development of AD symptoms. In a modification of the original AD mouse model induced by chronic epicutaneous application of ovalbumin (OVA) as a model allergen (Spergel et al., 1998), a skin barrier dysfunction is induced by repeated tapestripping of the skin, which disrupts the upper layers of the epidermis (Wang et al., 2007). Using our CCL17/EGFP reporter mice we could show that such mechanical irritation of the skin already leads to upregulation of CCL17 expression in cutaneous DC, as does epicutaneous treatment with DNFB, whereas CCL17 is not expressed in untreated skin (Alferink et al., 2003; Stutte et al., 2010). Upregulated expression of CCL17 in the skin was also observed in a transgenic mouse model of AD based on inducible expression of TSLP in keratinocytes. In this model only ccl17 but not $c c l 22$ mRNA was increased in the skin (Yoo et al., 2005). To directly study the pathogenic effects of constitutive CCL17 expression in the skin, Tamaki and colleagues generated transgenic mice, in which ccl17 is expressed under control of the human keratin 14 promoter. Expression of CCL17 in keratinocytes did not induce skin inflammation as such, whereas contact hypersensitivity (CHS) responses were differentially modulated by CCL17 depending on the contact sensitizer. In addition, increased numbers of Th2 cells and mast cells were recruited to the skin, and serum IgE levels were elevated (Tsunemi et al., 2006). Thus, when inflammation was induced by allergic sensitizers or irritants, CCL17 modified the inflammatory response and enhanced AD-like symptoms.

To obtain further insight into the pathogenic role of CCL17 in AD, we analyzed the development of AD-like symptoms in wild-type, CCL17/EGFP-reporter and CCL17knockout mice after tape-stripping of the skin and chronic application of OVA (Stutte et al., 2010). In this model, a small area of the back skin was tape-stripped and a patch soaked with OVA was applied to the skin for three consecutive periods of one week, separated by two week breaks. Sham treated mice showed no signs of AD, whereas OVA treatment lead to acanthosis and thickening of the dermal layer. We found that CCL17-deficiency significantly diminished dermal infiltration with mast cells, eosinophils and CD4 T cells, whereas the development of acanthosis was unaffected. OVA-specific IgG and IgE antibody production was decreased and levels of inflammatory cytokines in the draining LN and in the skin were significantly reduced. Taken together, the majority of AD symptoms were strongly ameliorated in CCL17-deficient mice (Stutte et al., 2010). In addition, we made the unexpected and interesting observation that LC of CCL17-deficient mice failed to emigrate 
from the affected skin area, despite the presence of acanthosis, which is indicative of an ongoing inflammatory process. This finding was also supported by the fact that OVAtreated CCL17-knockout mice had reduced total numbers of skin-derived DC in the draining LN. Furthermore, we tested the ability of LC to emigrate from the skin using epidermal sheets of DNFB sensitized ear skin. As already observed in the AD model, CCL17-deficient LC were strongly impaired in emigration from the epidermis in this shortterm assay. In contrast, LC emigration could be restored when recombinant (r) CCL17 was injected into the ear skin prior to DNFB treatment (Stutte et al., 2010). Thus, we could show that CCL17 is instrumental for the emigration of LC from the skin to the draining LN. Based on the reduced numbers of skin-derived DC in draining LN of OVA-treated CCL17deficient mice, it might be possible that the migration of $\mathrm{dDC}$ is also affected by CCL17. The main conclusion from these experiments is that CCL17 contributes to the pathogenesis of $\mathrm{AD}$ in two different ways: i) upregulation of the inflammatory chemokine CCL17 in cutaneous DC is essential for LC emigration from the skin and thus for priming of immune responses in the draining LN, and ii) CCL17 (together with other chemokines, such as CCL22 and CCL27) enhances the attraction of activated T cells from the circulation to the inflamed skin. Our finding on the role of CCL17 in the induction of LC emigration is in line with histological observations in the skin of AD patients that expression of TSLP, a major inducer of CCL17, correlates with enhanced migratory activity of LC (Guttman-Yassky et al., 2007; Soumelis et al., 2002). Already in 2001, Katou et al. reported that about $50 \%$ of LC in inflamed skin but not dermal DC express the CCR4 receptor, suggesting that CCR4 ligands also influence LC migration (Katou et al., 2001).

\subsubsection{Molecular processes involved in emigration of DC from the skin}

To access non-lymphoid peripheral tissues, immature DC utilize specific chemokine receptor-ligand interactions, such as CCR2-CCL2, CCR5-CCL5 and CCR6-CCL20. In the periphery they are mostly sessile and constantly scan for antigens. Once stimulated, peripheral DC mature and actively migrate to the draining $\mathrm{LN}$, where they act as professional antigen-presenting cells to prime naïve $\mathrm{T}$ cells and initiate antigen-specific responses. LC are located in between the basal keratinocyte layers of the epidermis and sample antigens that penetrated through the outer skin barrier - the stratum corneum. In the presence of danger signals induced by recognition of chemical or microbial antigens, or by physical stress, the sequential process of LC emigration from the skin to the draining LN is initiated. This process can be divided into the phases of mobilization, detachment, penetration of the basal membrane, interstitial migration within the dermis, traversing of the afferent lymphatic endothelium and transit to the LN within the lymphatic vessel (for review see (Alvarez et al., 2008)). Mobilization of LC is initiated by the pro-inflammatory cytokines TNF- $\alpha$ and IL-1 $\beta$, and passage through the basal membrane depends on the presence of matrix metalloproteinases (MMP), like MMP-2 and MMP-9 (Ratzinger et al., 2002). Epicutaneous sensitization increases CXCR4 and CCR7 expression on cutaneous DC (Dieu et al., 1998; Sallusto et al., 1998b; Sozzani et al., 1998). Blocking experiments with CXCR4 antagonists showed that CXCL12-CXCR4 interactions are required for transit of LC from the epidermis to the dermis (Kabashima et al., 2007), whereas CCR7 appears not to be essential for this step but rather for entry of the cells into the afferent lymphatics from the dermis (Ohl et al., 2004). In addition, CCL1-CCR8 interactions may also be involved in the migration of DC from the skin to the LN (Qu et al., 2004). 
Because of the impaired emigration of LC from the skin of CCL17-deficient mice in models of $\mathrm{AD}$ and CHS, we analyzed the responsiveness of CCL17-deficient BMDC to the CCR7 ligands CCL19 and CCL21, and the CXCR4 ligand CXCL12 in in vitro migration assays. In a transwell assay as well as a 3D migration assay in collagen gels, migration of CCL17deficient BMDC was partially impaired as compared to heterozygous control cells (Stutte et al., 2010). This migratory deficiency could be fully restored by addition of rCCL17 or rCCL22 to the cultures in a time- and concentration dependent manner. Because we did not detect major differences in the level of CCR7 expression, we hypothesized that CCL17 sensitizes CCR7 and CXCR4 for optimal responsiveness to their ligands, as previously reported for prostaglandin $\mathrm{E}_{2}\left(\mathrm{PGE}_{2}\right)$ in the case of CCR7 (Sánchez-Sánchez et al., 2006; Scandella et al., 2004). In this context, it is interesting that histamine and $\mathrm{PGE}_{2}$ were shown to upregulate CCL17 and CCL22 production in human myeloid DC (McIlroy et al., 2006). In addition to the observed changes in chemokine responsiveness of CCL17-deficient BMDC, a potential influence of CCL17 on the initial steps of LC emigration from the epidermis, like mobilization and detachment, as well as the production of MMP and penetration of the basal membrane still need to be investigated. Enzymatic activity of MMP-2 in epidermal and dermal cell suspensions was shown to be increased by IL-21 in wild-type but not IL-21 receptor (IL-21R)-deficient mice. Of note, AD-like symptoms, ccl17 mRNA expression in OVA-treated skin, and migration of cutaneous DC to CCR7 ligands were also reduced in IL21RKO mice (Jin et al., 2009b).

\subsubsection{Phenotypic differences of CCL17- and CCR4-deficient mice}

Because both CCL17 and CCL22 bind to CCR4 and thus may have redundant functions, one might anticipate that the amelioration of $\mathrm{AD}$ symptoms would be even more pronounced in CCR4-deficient mice compared to CCL17-deficient mice. Surprisingly, CCR4 knockout mice were not protected from the development of AD-like symptoms and exhibited normal emigration of DC from the skin after epicutaneous treatment with a contact sensitizer (Stutte et al., 2010). Similar findings were also reported by another group, showing that deficiency of CCR4 had no phenotype in the AD model, whereas absence of CCL8-CCR8 interactions diminished AD pathology (Islam et al., 2011). One possible explanation for this finding is the existence of an additional, as yet unknown receptor for CCL17. Inngjerdingen et al. demonstrated that CCL17 binding completely desensitized a calcium flux induced by CCL22, whereas CCL22 only partially reduced the calcium release to CCL17 (Inngjerdingen et al., 2000), indicating a different receptor binding activity of the two chemokines, or the presence of a second receptor for CCL17. In some studies, CCR8 was reported to function as a receptor for CCL17 (Bernardini et al., 1998; Inngjerdingen et al., 2000), but this finding is controversial and was disproven by others (Garlisi et al., 1999). For unknown reasons, genetic ablation of CCR4 also resulted in a deficiency of splenocytes to migrate to CCL3 (MIP-1 $\alpha$ ) (Chvatchko et al., 2000), which may also affect the phenotype of CCR4 knockout mice.

Another explanation for the different phenotype of CCL17- and CCR4-knockout mice may lie in differential expression patterns (Hashimoto et al., 2006; Vestergaard et al., 1999; 2000) and partially opposing functions of CCL17 and CCL22. In particular, CCL22-CCR4 interactions have been associated with enhanced recruitment of Treg (Curiel et al., 2004), whereas CCL17 appears to restrict the expansion of Treg in a mouse model of artherosclerosis (Weber et al., 2011). Furthermore, CCL22 is more potent in inducing 
integrin-dependent adhesion of CCR4 ${ }^{+}$Th cells (D'Ambrosio et al., 2002) and very rapidly induces CCR4 desensitization and receptor internalization from the cell surface. Thus, treatment of human Th2 cells with $1000 \mathrm{ng} / \mathrm{ml} \mathrm{CCL22}$ was sufficient to induce $90 \%$ internalization of CCR4, whereas no more than 20\% CCR4 internalization was triggered by the same amount of CCL17 (Mariani et al., 2004). D' Ambrosio et al. also suggested that CCL17 and CCL22 may act sequentially in the course of T cell extravasation into the skin, because only CCL17 is presented by endothelial cells in skin vessel, whereas CCL22 is more dominantly expressed in interstitial DC (D'Ambrosio et al., 2002). Another difference between CCL17 and CCL22 was reported regarding their ability to bind to the decoy receptor D6. Full length CCL22 had a much higher affinity to D6 than CCL17, and cleavage of CCL22 by the dipeptidyl-peptidase IV completely prevented binding to D6 (Bonecchi et al., 2004).

Taken together, CCL17 and CCL22 appear to be non-redundant in many aspects and differential, cell-type specific expression of these two chemokines may additionally account for the fact that genetic deficiency of CCL17 cannot be compensated by CCL22 in vivo (Stutte et al., 2010). On the other hand, targeting of CCR4 may have opposing effects on the immune response, as CCR4 is involved in both the attraction of pro-inflammatory $\mathrm{T}$ cells and of immunosuppressive Treg.

\section{Implication of CCL17, CCL22 and CCR4 in other diseases}

In addition to $\mathrm{AD}$, enhanced expression of CCL17 and CCL22, as well as elevated frequencies of CCR4 ${ }^{+} \mathrm{T}$ cells have been observed in asthma (Panina-Bordignon et al., 2001; Vijayanand et al., 2010) and rhinitis (Takeuchi et al., 2005; Terada et al., 2001), the two other forms of atopic diseases. In the case of asthma the pathogenic role of the CCL17/CCL22CCR4 axis is still controversial (Pease, 2006), as some reports demonstrate efficient improvement of disease symptoms after CCR4 or CCL17 blockade (Kawasaki et al., 2001; Perros et al., 2009; Vijayanand et al., 2010), whereas others do not ( Chvatchko et al., 2000; Conroy et al., 2003). As already mentioned above, enhanced expression of CCL17 and CCL22 has also been observed in allergic contact dermatitis (Bäumer et al., 2004; Goebeler et al., 2001; Kamsteeg et al., 2010; Martín et al., 2002), and contact hypersensitivity responses were significantly inhibited in CCL17-deficient mice (Alferink et al., 2003). Regarding nonallergic diseases, CCL17 has recently been shown to enhance the formation of artherosclerotic lesions in mice by inhibition of Treg cell expansion (Weber et al., 2011). Furthermore, deficiency in CCL17 or CCR4 prolongs graft survival in mouse models of cardiac allograft rejection (Alferink et al., 2003; Hüser et al., 2005).

As CCL17 expression is strongly upregulated in response to TLR stimulation (Lieberam \& Förster, 1999; Alferink et al., 2003), it is possible that this chemokine is also involved in the defence against microbial infections. After cutaneous infection with the murine filaria Litomosoides sigmodontis, CCL17 was shown to control filarial worm load as a consequence of reduced mast cell dependent larval entry (Specht et al., 2011). In contrast, blockade of CCL17 but not CCL22 enhanced protection from murine pulmonary aspergillosis, and CCR4-deficient mice were similarly protected (Carpenter \& Hogaboam, 2005). CCL17 production induced by NKT cell activation licensed splenic DC for efficient crosspresentation of OVA and stimulation of CTL responses (Semmling et al., 2010). Thus, CCL17 may also be involved in the defence against viral infections, although this has not been directly assessed so far. 


\section{Perspectives on chemokines and chemokine receptors as therapeutic targets in AD}

Because of the crucial role of chemokine/chemokine-receptor interactions in the pathogenesis of allergic responses, it seems very attractive to use specific inhibitors, like neutralizing antibodies or small molecule antagonists, as therapeutic drugs to prevent or dampen the inflammatory reaction. Many inhibitors of chemokines and their receptors have already been developed and are currently tested in various disease models and in clinical studies (for recent reviews see (Garin \& Proudfoot, 2011; Mackay, 2008; Pease, 2011)) However, the pleiotropic action of many chemokines and the frequent redundancies in the system hamper the development of efficient drugs and their approval for clinical use. Nevertheless, there is still optimism that chemokines and their receptors are promising targets for treatment of inflammatory diseases.

In the case of CCR4 at least four different small molecule inhibitors have been developed and successfully tested in vitro as well as in T cell migration models in mice (Nakagami et al., 2010; Pease, 2011; Sato et al., 2009). As indicated by the fact that CCR4 knockout mice develop AD-like symptoms (Islam et al., 2011; Stutte et al., 2010) and OVA-induced lung inflammation (Chvatchko et al., 2000) comparable to wild-type mice, blockade of CCR4 alone may not be sufficient to prevent these allergic reactions. In two studies addressing skin inflammation, simultaneous blockade of CCR4- and CCR10-ligands, or of CCR4 and the CCR10 ligand CCL27 was shown to be required for efficient inhibition of contact hypersensitivity at the time of challenge, or for homing of allergen-specific $T$ cells to the skin (Mirshahpanah et al., 2008; Reiss et al., 2001). In another study, however, treatment with anti-CCL27 alone led to a significant inhibition of CHS and development of AD-like symptoms (Homey et al., 2002). As discussed above the amelioration of AD symptoms in CCL17-deficient mice but not CCR4-deficient mice indicates the presence of an additional receptor for CCL17, in particular with relevance for the emigration of LC from the skin. In addition, differences in the function of CCL17 and CCL22 regarding the attraction of Treg versus $\mathrm{T}$ helper cells may limit the usefulness of CCR4 antagonists in the treatment of allergic reactions. In fact, CCR4 blockade has also been proposed as a means to reduce attraction of tumor infiltrating Treg in cancer therapy (Yang et al., 2011). Therefore, it may be reasonable to also consider neutralization of certain chemokine ligands like CCL17 and CCL27 for therapy of AD, as an alternative to the blockade of chemokine receptors.

\section{Acknowledgment}

We are grateful to Heike Weighardt, Sonja Didovic and Theresa Globisch for comments on the manuscript. This work was supported by the Deutsche Forschungsgemeinschaft through SFB 704.

\section{References}

Acosta-Rodriguez, E. V., Rivino, L., Geginat, J., Jarrossay, D., Gattorno, M., Lanzavecchia, A., Sallusto, F., \& Napolitani, G. (2007). Surface phenotype and antigenic specificity of human interleukin 17-producing $\mathrm{T}$ helper memory cells. Nat. Immunol. 8, 639-646. 
Alferink, J., Lieberam, I., Reindl, W., Behrens, A., Weiss, S., Hüser, N., Gerauer, K., Ross, R., Reske-Kunz, A. B., Ahmad-Nejad, P., et al. (2003). Compartmentalized production of CCL17 in vivo: strong inducibility in peripheral dendritic cells contrasts selective absence from the spleen. J. Exp. Med. 197, 585-599.

Alvarez, D., Vollmann, E. H., \& Andrian, von, U. H. (2008). Mechanisms and consequences of dendritic cell migration. Immunity 29, 325-342.

Annunziato, F., Cosmi, L., Santarlasci, V., Maggi, L., Liotta, F., Mazzinghi, B., Parente, E., Fili, L., Ferri, S., Frosali, F., et al. (2007). Phenotypic and functional features of human Th17 cells. J. Exp. Med. 204, 1849-1861.

Aragay, A. M., Mellado, M., Frade, J. M., Martin, A. M., Jimenez-Sainz, M. C., Martinez-A, C., \& Mayor, F. (1998). Monocyte chemoattractant protein-1-induced CCR2B receptor desensitization mediated by the $\mathrm{G}$ protein-coupled receptor kinase 2. Proc. Natl. Acad. Sci. U.S.A. 95, 2985-2990.

Barnes, K. C. (2010). An update on the genetics of atopic dermatitis: scratching the surface in 2009. J. Allergy Clin. Immunol. 125, 16-29.

Bäumer, W., Seegers, U., Braun, M., Tschernig, T., \& Kietzmann, M. (2004). TARC and RANTES, but not CTACK, are induced in two models of allergic contact dermatitis. Effects of cilomilast and diflorasone diacetate on T-cell-attracting chemokines. Br. J. Dermatol. 151, 823-830.

Bernardini, G., Hedrick, J., Sozzani, S., Luini, W., Spinetti, G., Weiss, M., Menon, S., Zlotnik, A., Mantovani, A., Santoni, A., et al. (1998). Identification of the CC chemokines TARC and macrophage inflammatory protein-1 beta as novel functional ligands for the CCR8 receptor. Eur. J. Immunol. 28, 582-588.

Bieber, T. (2008). Atopic dermatitis. N. Engl. J. Med. 358, 1483-1494.

Bochner, B. S., Bickel, C. A., Taylor, M. L., MacGlashan, D. W., Gray, P. W., Raport, C. J., \& Godiska, R. (1999). Macrophage-derived chemokine induces human eosinophil chemotaxis in a CC chemokine receptor 3- and CC chemokine receptor 4independent manner. J. Allergy Clin. Immunol. 103, 527-532.

Bonecchi, R., Locati, M., Galliera, E., Vulcano, M., Sironi, M., Fra, A. M., Gobbi, M., Vecchi, A., Sozzani, S., Haribabu, B., et al. (2004). Differential recognition and scavenging of native and truncated macrophage-derived chemokine (macrophage-derived chemokine/CC chemokine ligand 22) by the D6 decoy receptor. J. Immunol. 172, 4972-4976.

Bussmann, C., Maintz, L., Hart, J., Allam, J.-P., Vrtala, S., Chen, K.-W., Bieber, T., Thomas, W. R., Valenta, R., Zuberbier, T., et al. (2007). Clinical improvement and immunological changes in atopic dermatitis patients undergoing subcutaneous immunotherapy with a house dust mite allergoid: a pilot study. Clin. Exp. Allergy $37,1277-1285$.

Carmi-Levy, I., Homey, B., \& Soumelis, V. (2011). A Modular View of Cytokine Networks in Atopic Dermatitis. Clin Rev Allergy Immunol., in press.

Carpenter, K. J., \& Hogaboam, C. M. (2005). Immunosuppressive effects of CCL17 on pulmonary antifungal responses during pulmonary invasive aspergillosis. Infect. Immun. 73, 7198-7207. 
Charo, I. F., \& Ransohoff, R. M. (2006). The many roles of chemokines and chemokine receptors in inflammation. N. Engl. J. Med. 354, 610-621.

Chvatchko, Y., Hoogewerf, A. J., Meyer, A., Alouani, S., Juillard, P., Buser, R., Conquet, F., Proudfoot, A. E., Wells, T. N., \& Power, C. A. (2000). A key role for CC chemokine receptor 4 in lipopolysaccharide-induced endotoxic shock. J. Exp. Med. 191, 1755-1764.

Clemetson, K. J., Clemetson, J. M., Proudfoot, A. E., Power, C. A., Baggiolini, M., \& Wells, T. N. (2000). Functional expression of CCR1, CCR3, CCR4, and CXCR4 chemokine receptors on human platelets. Blood 96, 4046-4054.

Comerford, I., Milasta, S., Morrow, V., Milligan, G., \& Nibbs, R. (2006). The chemokine receptor CCX-CKR mediates effective scavenging of CCL19 in vitro. Eur. J. Immunol. 36, 1904-1916.

Comerford, I., \& McColl, S. R. (2011). Mini-review series: focus on chemokines. Immunol Cell Biol 89, 183-184.

Conroy, D. M., Jopling, L. A., Lloyd, C. M., Hodge, M. R., Andrew, D. P., Williams, T. J., Pease, J. E., and Sabroe, I. (2003). CCR4 blockade does not inhibit allergic airways inflammation. J. Leukoc. Biol. 74, 558-563.

Curiel, T. J., Coukos, G., Zou, L., Alvarez, X., Cheng, P., Mottram, P., Evdemon-Hogan, M., Conejo-Garcia, J. R., Zhang, L., Burow, M., et al. (2004). Specific recruitment of regulatory $\mathrm{T}$ cells in ovarian carcinoma fosters immune privilege and predicts reduced survival. Nat. Med. 10, 942-949.

Cyster, J. G. (2005). Chemokines, sphingosine-1-phosphate, and cell migration in secondary lymphoid organs. Annu. Rev. Immunol. 23, 127-159.

D'Ambrosio, D. (2005). Targeting chemoattractant receptors in allergic inflammation. Curr Drug Targets Inflamm Allergy 4, 163-167.

D'Ambrosio, D., Albanesi, C., Lang, R., Girolomoni, G., Sinigaglia, F.,\& Laudanna, C. (2002). Quantitative differences in chemokine receptor engagement generate diversity in integrin-dependent lymphocyte adhesion. J. Immunol. 169, 2303-2312.

D'Ambrosio, D., Iellem, A., Bonecchi, R., Mazzeo, D., Sozzani, S., Mantovani, A., \& Sinigaglia, F. (1998). Selective up-regulation of chemokine receptors CCR4 and CCR8 upon activation of polarized human type 2 Th cells. J. Immunol. 161, 51115115.

Darsow, U., Vieluf, D., \& Ring, J. (1996). The atopy patch test: an increased rate of reactivity in patients who have an air-exposed pattern of atopic eczema. Br. J. Dermatol. 135, 182-186.

Dieu, M. C., Vanbervliet, B., Vicari, A., Bridon, J. M., Oldham, E., Aït-Yahia, S., Brière, F., Zlotnik, A., Lebecque, S., \& Caux, C. (1998). Selective recruitment of immature and mature dendritic cells by distinct chemokines expressed in different anatomic sites. J. Exp. Med. 188, 373-386.

Ebert, L. M., \& McColl, S. R. (2002). Up-regulation of CCR5 and CCR6 on distinct subpopulations of antigen-activated CD4+ T lymphocytes. J. Immunol. 168, 65-72.

Ebner, S., Nguyen, V. A., Forstner, M., Wang, Y.-H., Wolfram, D., Liu, Y.-J., \& Romani, N. (2007). Thymic stromal lymphopoietin converts human epidermal Langerhans cells 
into antigen-presenting cells that induce proallergic T cells. J. Allergy Clin. Immunol. 119, 982-990.

Faffe, D. S., Whitehead, T., Moore, P. E., Baraldo, S., Flynt, L., Bourgeois, K., Panettieri, R. A., \& Shore, S. A. (2003). IL-13 and IL-4 promote TARC release in human airway smooth muscle cells: role of IL-4 receptor genotype. Am. J. Physiol. Lung Cell Mol. Physiol. 285, L907-14.

Fallon, P. G., Sasaki, T., Sandilands, A., Campbell, L. E., Saunders, S. P., Mangan, N. E., Callanan, J. J., Kawasaki, H., Shiohama, A., Kubo, A., et al. (2009). A homozygous frameshift mutation in the mouse Flg gene facilitates enhanced percutaneous allergen priming. Nat. Genet. 41, 602-608.

Fujita, H., Asahina, A., Sugaya, M., Nakamura, K., Gao, P., Fujiwara, H., \& Tamaki, K. (2005). Differential production of Th1- and Th2-type chemokines by mouse Langerhans cells and splenic dendritic cells. J. Invest. Dermatol. 124, 343-350.

Fujita, H., Shemer, A., Suárez-Fariñas, M., Johnson-Huang, L. M., Tintle, S., Cardinale, I., Fuentes-Duculan, J., Novitskaya, I., Carucci, J. A., Krueger, J. G., et al. (2011). Lesional dendritic cells in patients with chronic atopic dermatitis and psoriasis exhibit parallel ability to activate T-cell subsets. J. Allergy Clin. Immunol., 128, 574582.

Furukawa, H., Takahashi, M., Nakamura, K., \& Kaneko, F. (2004). Effect of an antiallergic drug (Olopatadine hydrochloride) on TARC/CCL17 and MDC/CCL22 production by PBMCs from patients with atopic dermatitis. J. Dermatol. Sci. 36, 165-172.

Garin, A., \& Proudfoot, A. E. I. (2011). Chemokines as targets for therapy. Ex.l Cell Research $317,602-612$.

Garlisi, C. G., Xiao, H., Tian, F., Hedrick, J. A., Billah, M. M., Egan, R. W., \& Umland, S. P. (1999). The assignment of chemokine-chemokine receptor pairs: TARC and MIP-1 beta are not ligands for human CC-chemokine receptor 8. Eur. J. Immunol. 29, 3210-3215.

Goebeler, M., Trautmann, A., Voss, A., Bröcker, E. V., Toksoy, A., \& Gillitzer, R. (2001). Differential and sequential expression of multiple chemokines during elicitation of allergic contact hypersensitivity. Am. J. Pathol. 158, 431-440.

Gombert, M., Dieu-Nosjean, M.-C., Winterberg, F., Bünemann, E., Kubitza, R. C., Da Cunha, L., Haahtela, A., Lehtimäki, S., Müller, A., Rieker, J., et al. (2005). CCL1-CCR8 interactions: an axis mediating the recruitment of $\mathrm{T}$ cells and Langerhans-type dendritic cells to sites of atopic skin inflammation. J. Immunol. 174, 5082-5091.

Gosling, J., Dairaghi, D. J., Wang, Y., Hanley, M., Talbot, D., Miao, Z., \& Schall, T. J. (2000). Cutting edge: identification of a novel chemokine receptor that binds dendritic cell- and T cell-active chemokines including ELC, SLC, and TECK. J. Immunol. 164, 2851-2856.

Grewe, M., Bruijnzeel-Koomen, C. A., Schöpf, E., Thepen, T., Langeveld-Wildschut, A. G., Ruzicka, T., \& Krutmann, J. (1998). A role for Th1 and Th2 cells in the immunopathogenesis of atopic dermatitis. Immunol. Today 19, 359-361.

Gros, E., Bussmann, C., Bieber, T., Förster, I., \& Novak, N. (2009). Expression of chemokines and chemokine receptors in lesional and nonlesional upper skin of patients with atopic dermatitis. J. Allergy Clin. Immunol. 124, 753-60. 
Guttman-Yassky, E., Lowes, M. A., Fuentes-Duculan, J., Whynot, J., Novitskaya, I., Cardinale, I., Haider, A., Khatcherian, A., Carucci, J. A., Bergman, R., et al. (2007). Major differences in inflammatory dendritic cells and their products distinguish atopic dermatitis from psoriasis. J. Allergy Clin. Immunol. 119, 1210-1217.

Günther, C., Bello-Fernandez, C., Kopp, T., Kund, J., Carballido-Perrig, N., Hinteregger, S., Fassl, S., Schwärzler, C., Lametschwandtner, G., Stingl, G., et al. (2005). CCL18 is expressed in atopic dermatitis and mediates skin homing of human memory $\mathrm{T}$ cells. J. Immunol. 174, 1723-1728.

Hansell, C., \& Nibbs, R. (2007). Professional and part-time chemokine decoys in the resolution of inflammation. Sci. STKE 2007, pe18.

Hashimoto, S., Nakamura, K., Oyama, N., Kaneko, F., Tsunemi, Y., Saeki, H., \& Tamaki, K. (2006). Macrophage-derived chemokine (MDC)/CCL22 produced by monocyte derived dendritic cells reflects the disease activity in patients with atopic dermatitis. J. Dermatol. Sci. 44, 93-99.

Hayashida, S., Uchi, H., Moroi, Y., \& Furue, M. (2011a). Decrease in circulating Th17 cells correlates with increased levels of CCL17, IgE and eosinophils in atopic dermatitis. J. Dermatol. Sci. 61, 180-186.

Hayashida, S., Uchi, H., Takeuchi, S., Esaki, H., Moroi, Y., \& Furue, M. (2011b). Significant correlation of serum IL-22 levels with CCL17 levels in atopic dermatitis. J. Dermatol. Sci. 61, 78-79.

Heijink, I. H., Marcel Kies, P., van Oosterhout, A. J. M., Postma, D. S., Kauffman, H. F.,\& Vellenga, E. (2007). Der p, IL-4, and TGF-beta cooperatively induce EGFRdependent TARC expression in airway epithelium. Am. J. Respir. Cell Mol. Biol. 36, 351-359.

Hiroyama, T., Iwama, A., Nakamura, Y., \&Nakauchi, H. (2001). Fractalkine shares signal sequence with TARC: gene structures and expression profiles of two chemokine genes. Genomics 75, 3-5.

Holmes, W. E., Lee, J., Kuang, W. J., Rice, G. C., \& Wood, W. I. (1991). Structure and functional expression of a human interleukin-8 receptor. Science 253, 1278-1280.

Homey, B., Alenius, H., Müller, A., Soto, H., Bowman, E. P., Yuan, W., McEvoy, L., Lauerma, A. I., Assmann, T., Bünemann, E., et al. (2002). CCL27-CCR10 interactions regulate T cell-mediated skin inflammation. Nat. Med. 8, 157-165.

Homey, B., Steinhoff, M., Ruzicka, T., \& Leung, D. Y. M. (2006). Cytokines and chemokines orchestrate atopic skin inflammation. J. Allergy Clin. Immunol. 118, 178-189.

Hudak, S., Hagen, M., Liu, Y., Catron, D., Oldham, E., McEvoy, L. M., \& Bowman, E. P. (2002). Immune surveillance and effector functions of CCR10(+) skin homing $\mathrm{T}$ cells. J. Immunol. 169, 1189-1196.

Hüser, N., Tertilt, C., Gerauer, K., Maier, S., Traeger, T., Assfalg, V., Reiter, R., Heidecke, C.D.,\& Pfeffer, K. (2005). CCR4-deficient mice show prolonged graft survival in a chronic cardiac transplant rejection model. Eur. J. Immunol. 35, 128-138.

Iellem, A., Mariani, M., Lang, R., Recalde, H., Panina-Bordignon, P., Simigaglia, F., \& D'Ambrosio, D. (2001). Unique chemotactic response profile and specific expression of chemokine receptors CCR4 and CCR8 by CD4(+)CD25(+) regulatory T cells. J. Exp. Med. 194, 847-853. 
Imai, T., Yoshida, T., Baba, M., Nishimura, M., Kakizaki, M., \& Yoshie, O. (1996). Molecular cloning of a novel $\mathrm{T}$ cell-directed CC chemokine expressed in thymus by signal sequence trap using Epstein-Barr virus vector. J. Biol. Chem. 271, 21514-21521.

Imai, T., Nagira, M., Takagi, S., Kakizaki, M., Nishimura, M., Wang, J., Gray, P. W., Matsushima, K., \& Yoshie, O. (1999). Selective recruitment of CCR4-bearing Th2 cells toward antigen-presenting cells by the CC chemokines thymus and activationregulated chemokine and macrophage-derived chemokine. Int. Immunol. 11, 81-88.

Inngjerdingen, M., Damaj, B., \& Maghazachi, A. A. (2000). Human NK cells express CC chemokine receptors 4 and 8 and respond to thymus and activation-regulated chemokine, macrophage-derived chemokine, and I-309. J. Immunol. 164, 4048-4054.

Islam, S. A., Chang, D. S., Colvin, R. A., Byrne, M. H., McCully, M. L., Moser, B., Lira, S. A., Charo, I. F., \& Luster, A. D. (2011). Mouse CCL8, a CCR8 agonist, promotes atopic dermatitis by recruiting IL-5+ T(H)2 cells. Nat. Immunol. 12, 167-177.

Jin, H., He, R., Oyoshi, M., \& Geha, R. S. (2009a). Animal models of atopic dermatitis. J. Invest. Dermatol. 129, 31-40.

Jin, H., Oyoshi, M. K., Le, Y., Bianchi, T., Koduru, S., Mathias, C. B., Kumar, L., Le Bras, S., Young, D., Collins, M., et al. (2009b). IL-21R is essential for epicutaneous sensitization and allergic skin inflammation in humans and mice. J. Clin. Invest. 119, 47-60.

Kabashima, K., Shiraishi, N., Sugita, K., Mori, T., Onoue, A., Kobayashi, M., Sakabe, J.-I., Yoshiki, R., Tamamura, H., Fujii, N., et al. (2007). CXCL12-CXCR4 engagement is required for migration of cutaneous dendritic cells. Am. J. Pathol. 171, 1249-1257.

Kakinuma, T., Nakamura, K., Wakugawa, M., Mitsui, H., Tada, Y., Saeki, H., Torii, H., Komine, M., Asahina, A., \& Tamaki, K. (2002). Serum macrophage-derived chemokine (MDC) levels are closely related with the disease activity of atopic dermatitis. Clin. Exp. Immunol. 127, 270-273.

Kakinuma, T., Nakamura, K., Wakugawa, M., Mitsui, H., Tada, Y., Saeki, H., Torii, H., Asahina, A., Onai, N., Matsushima, K., et al. (2001). Thymus and activationregulated chemokine in atopic dermatitis: Serum thymus and activation-regulated chemokine level is closely related with disease activity. J. Allergy Clin. Immunol. 107, 535-541.

Kamsteeg, M., Jansen, P. A. M., van Vlijmen-Willems, I. M. J. J., van Erp, P. E. J., RodijkOlthuis, D., van der Valk, P. G., Feuth, T., Zeeuwen, P. L. J. M., \& Schalkwijk, J. (2010). Molecular diagnostics of psoriasis, atopic dermatitis, allergic contact dermatitis and irritant contact dermatitis. Br. J. Dermatol. 162, 568-578.

Kang, S., Xie, J., Ma, S., Liao, W., Zhang, J., \& Luo, R. (2010). Targeted knock down of CCL22 and CCL17 by siRNA during DC differentiation and maturation affects the recruitment of T subsets. Immunobiology 215, 153-162.

Katou, F., Ohtani, H., Nakayama, T., Ono, K., Matsushima, K., Saaristo, A., Nagura, H., Yoshie, O., \& Motegi, K. (2001). Macrophage-derived chemokine (MDC/CCL22) and CCR4 are involved in the formation of T lymphocyte-dendritic cell clusters in human inflamed skin and secondary lymphoid tissue. Am. J. Pathol. 158, 1263-1270.

Kawasaki, S., Takizawa, H., Yoneyama, H., Nakayama, T., Fujisawa, R., Izumizaki, M., Imai, T., Yoshie, O., Homma, I., Yamamoto, K., et al. (2001). Intervention of thymus and 
activation-regulated chemokine attenuates the development of allergic airway inflammation and hyperresponsiveness in mice. J. Immunol. 166, 2055-2062.

Kim, C. H., Johnston, B., \& Butcher, E. C. (2002). Trafficking machinery of NKT cells: shared and differential chemokine receptor expression among $\mathrm{V}$ alpha $24(+) \mathrm{V}$ beta $11(+)$ NKT cell subsets with distinct cytokine-producing capacity. Blood 100, 11-16.

Koga, C., Kabashima, K., Shiraishi, N., Kobayashi, M., \& Tokura, Y. (2008). Possible Pathogenic Role of Th17 Cells for Atopic Dermatitis. J. Investig. Dermatol. 128, 26252630.

Kondo, T., \& Takiguchi, M. (2009). Human memory CCR4+CD8+ T cell subset has the ability to produce multiple cytokines. Int. Immunol. 21, 523-532.

Kwon, Y. S., Oh, S. H., Wu, W. H., Bae, B. G., Lee, H. J., Lee, M.-G., \& Lee, K. H. (2010). CC chemokines as potential immunologic markers correlated with clinical improvement of atopic dermatitis patients by immunotherapy. Exp. Dermatol. 19, 246-251.

Liddiard, K., Welch, J. S., Lozach, J., Heinz, S., Glass, C. K., \& Greaves, D. R. (2006). Interleukin-4 induction of the CC chemokine TARC (CCL17) in murine macrophages is mediated by multiple STAT6 sites in the TARC gene promoter. BMC Mol. Bio.l 7, 45.

Lieberam, I., \& Förster, I. (1999). The murine beta-chemokine TARC is expressed by subsets of dendritic cells and attracts primed CD4+ T cells. Eur. J. Immunol. 29, 2684-2694.

Liu, L. Y., Bates, M. E., Jarjour, N. N., Busse, W. W., Bertics, P. J., \& Kelly, E. A. B. (2007). Generation of Th1 and Th2 chemokines by human eosinophils: evidence for a critical role of TNF-alpha. J. Immunol. 179, 4840-4848.

Loetscher, M., Geiser, T., O'Reilly, T., Zwahlen, R., Baggiolini, M., \& Moser, B. (1994). Cloning of a human seven-transmembrane domain receptor, LESTR, that is highly expressed in leukocytes. J. Biol. Chem. 269, 232-237.

Lowes, M. A., Kikuchi, T., Fuentes-Duculan, J., Cardinale, I., Zaba, L. C., Haider, A. S., Bowman, E. P., \& Krueger, J. G. (2008). Psoriasis vulgaris lesions contain discrete populations of Th1 and Th17 T cells. J. Invest. Dermatol. 128, 1207-1211.

Mackay, C. R. (2008). Moving targets: cell migration inhibitors as new anti-inflammatory therapies. Nat. Immunol. 9, 988-998.

Mariani, M., Lang, R., Binda, E., Panina-Bordignon, P., \& D'Ambrosio, D. (2004). Dominance of CCL22 over CCL17 in induction of chemokine receptor CCR4 desensitization and internalization on human Th2 cells. Eur. J. Immunol. 34, 231-240.

Martín, A., Gallino, N., Gagliardi, J., Ortiz, S., Lascano, A. R., Diller, A., Daraio, M. C., Kahn, A., Mariani, A. L., \& Serra, H. M. (2002). Early inflammatory markers in elicitation of allergic contact dermatitis. BMC Dermatol. 2, 9-17.

Mashikian, M. V., Ryan, T. C., Seman, A., Brazer, W., Center, D. M., \& Cruikshank, W. W. (1999). Reciprocal desensitization of CCR5 and CD4 is mediated by IL-16 and macrophage-inflammatory protein-1 beta, respectively. J. Immunol. 163, 31233130 .

Matsuda, H., Watanabe, N., Geba, G. P., Sperl, J., Tsudzuki, M., Hiroi, J., Matsumoto, M., Ushio, H., Saito, S., Askenase, P. W., et al. (1997). Development of atopic 
dermatitis-like skin lesion with $\operatorname{IgE}$ hyperproduction in $\mathrm{NC} / \mathrm{Nga}$ mice. Int. Immunol. 9, 461-466.

McIlroy, A., Caron, G., Blanchard, S., Frémaux, I., Duluc, D., Delneste, Y., Chevailler, A., \& Jeannin, P. (2006). Histamine and prostaglandin E up-regulate the production of Th2-attracting chemokines (CCL17 and CCL22) and down-regulate IFN-gammainduced CXCL10 production by immature human dendritic cells. Immunology 117, 507-516.

Mirshahpanah, P., Li, Y.-Y. Y., Burkhardt, N., Asadullah, K., \& Zollner, T. M. (2008). CCR4 and CCR10 ligands play additive roles in mouse contact hypersensitivity. Exp. Dermatol. 17, 30-34.

Moniaga, C. S., Egawa, G., Kawasaki, H., Hara-Chikuma, M., Honda, T., Tanizaki, H., Nakajima, S., Otsuka, A., Matsuoka, H., Kubo, A., et al. (2010). Flaky tail mouse denotes human atopic dermatitis in the steady state and by topical application with Dermatophagoides pteronyssinus extract. Am. J. Pathol. 176, 2385-2393.

Monick, M. M., Powers, L. S., Hassan, I., Groskreutz, D., Yarovinsky, T. O., Barrett, C. W., Castilow, E. M., Tifrea, D., Varga, S. M., \& Hunninghake, G. W. (2007). Respiratory syncytial virus synergizes with Th2 cytokines to induce optimal levels of TARC/CCL17. J. Immunol. 179, 1648-1658.

Morita, E., Takahashi, H., Niihara, H., Dekio, I., Sumikawa, Y., Murakami, Y., \& Matsunaka, H. (2010). Stratum corneum TARC level is a new indicator of lesional skin inflammation in atopic dermatitis. Allergy 65, 1166-1172.

Nakagami, Y., Kawashima, K., Etori, M., Yonekubo, K., Suzuki, C., Jojima, T., Kuribayashi, T., Nara, F., \& Yamashita, M. (2010). A Novel CC Chemokine Receptor 4 Antagonist RS-1269 Inhibits Ovalbumin-Induced Ear Swelling and Lipopolysaccharide-Induced Endotoxic Shock in Mice. Basic \& Clinical Pharmacology $\mathcal{E}$ Toxicology 107, 793-797.

Nakahigashi, K., Kabashima, K., Ikoma, A., Verkman, A. S., Miyachi, Y., \& Hara-Chikuma, M. (2010). Upregulation of Aquaporin-3 Is Involved in Keratinocyte Proliferation and Epidermal Hyperplasia. J. Invest. Dermatol. 131, 865-873.

Nakayama, T., Hieshima, K., Nagakubo, D., Sato, E., Nakayama, M., Kawa, K.,\& Yoshie, O. (2004). Selective induction of Th2-attracting chemokines CCL17 and CCL22 in human B cells by latent membrane protein 1 of Epstein-Barr virus. J. Virol. 78, 16651674.

Nograles, K. E., Zaba, L. C., Shemer, A., Fuentes-Duculan, J., Cardinale, I., Kikuchi, T., Ramon, M., Bergman, R., Krueger, J. G., \& Guttman-Yassky, E. (2009). IL-22producing "T22" T cells account for upregulated IL-22 in atopic dermatitis despite reduced IL-17-producing TH17 T cells. J. Allergy Clin. Immunol. 123, 1244-1252.

Nograles, K. E., Zaba, L. C., Guttman-Yassky, E., Fuentes-Duculan, J., Suárez-Fariñas, M., Cardinale, I., Khatcherian, A., Gonzalez, J., Pierson, K. C., White, T. R., et al. (2008). Th17 cytokines interleukin (IL)-17 and IL-22 modulate distinct inflammatory and keratinocyte-response pathways. Br. J. Dermatol. 159, 1092-1102.

Novak, N., \& Bieber, T. (2005). The role of dendritic cell subtypes in the pathophysiology of atopic dermatitis. J. Am. Acad. Dermatol. 53, S171-6. 
Novak, N., \& Simon, D. (2011). Atopic dermatitis - from new pathophysiologic insights to individualized therapy. Allergy 66, 830-839.

O'Regan, G. M., \& Irvine, A. D. (2010). The role of filaggrin in the atopic diathesis. Clin. Exp. Allergy 40, 965-972.

Ohl, L., Mohaupt, M., Czeloth, N., Hintzen, G., Kiafard, Z., Zwirner, J., Blankenstein, T., Henning, G., \& Förster, R. (2004). CCR7 governs skin dendritic cell migration under inflammatory and steady-state conditions. Immunity 21, 279-288.

Owczarek, W., Paplinska, M., Targowski, T., Jahnz-Rozyk, K., Paluchowska, E., Kucharczyk, A., \& Kasztalewicz, B. (2010). Analysis of eotaxin 1/CCL11, eotaxin 2/CCL24 and eotaxin 3/CCL26 expression in lesional and non-lesional skin of patients with atopic dermatitis. Cytokine 50, 181-185.

Oyoshi, M. K., Murphy, G. F., \& Geha, R. S. (2009). Filaggrin-deficient mice exhibit TH17dominated skin inflammation and permissiveness to epicutaneous sensitization with protein antigen. J. Allergy Clin. Immunol. 124, 485-93, 493.e1.

Panina-Bordignon, P., Papi, A., Mariani, M., Di Lucia, P., Casoni, G., Bellettato, C., Buonsanti, C., Miotto, D., Mapp, C., Villa, A., et al. (2001). The C-C chemokine receptors CCR4 and CCR8 identify airway $\mathrm{T}$ cells of allergen-challenged atopic asthmatics. J. Clin. Invest. 107, 1357-1364.

Pastore, S., Mascia, F., Mariotti, F., Dattilo, C., \& Girolomoni, G. (2004). Chemokine networks in inflammatory skin diseases. Eur. J. Dermatol. 14, 203-208.

Pease, J. E. (2006). Asthma, allergy and chemokines. Curr Drug Targets 7, 3-12.

Pease, J. E. (2011). Targeting chemokine receptors in allergic disease. Biochem. J. 434, 11-24.

Pease, J. E., \& Williams, T. J. (2006). Chemokines and their receptors in allergic disease. J. Allergy Clin. Immunol. 118, 305-18; quiz 319-20.

Perros, F., Hoogsteden, H. C., Coyle, A. J., Lambrecht, B. N., \& Hammad, H. (2009). Blockade of CCR4 in a humanized model of asthma reveals a critical role for DCderived CCL17 and CCL22 in attracting Th2 cells and inducing airway inflammation. Allergy 64, 995-1002.

Pivarcsi, A., Gombert, M., Dieu-Nosjean, M.-C., Lauerma, A., Kubitza, R., Meller, S., Rieker, J., Müller, A., Da Cunha, L., Haahtela, A., et al. (2004). CC chemokine ligand 18, an atopic dermatitis-associated and dendritic cell-derived chemokine, is regulated by staphylococcal products and allergen exposure. J. Immunol. 173, 5810-5817.

Qu, C., Edwards, E. W., Tacke, F., Angeli, V., Llodrá, J., Sanchez-Schmitz, G., Garin, A., Haque, N. S., Peters, W., van Rooijen, N., et al. (2004). Role of CCR8 and other chemokine pathways in the migration of monocyte-derived dendritic cells to lymph nodes. J. Exp. Med. 200, 1231-1241.

Randolph, G. J., Ochando, J., \& Partida-Sánchez, S. (2008). Migration of dendritic cell subsets and their precursors. Annu. Rev. Immunol. 26, 293-316.

Ransohoff, R. M. (2009). Chemokines and chemokine receptors: standing at the crossroads of immunobiology and neurobiology. Immunity 31, 711-721.

Ratzinger, G., Stoitzner, P., Ebner, S., Lutz, M. B., Layton, G. T., Rainer, C., Senior, R. M., Shipley, J. M., Fritsch, P., Schuler, G., et al. (2002). Matrix metalloproteinases 9 and 2 are necessary for the migration of Langerhans cells and dermal dendritic cells from human and murine skin. J. Immunol. 168, 4361-4371. 
Reiss, Y., Proudfoot, A. E., Power, C. A., Campbell, J. J., \& Butcher, E. C. (2001). CC chemokine receptor (CCR)4 and the CCR10 ligand cutaneous $\mathrm{T}$ cell-attracting chemokine (CTACK) in lymphocyte trafficking to inflamed skin. J. Exp. Med. 194, 1541-1547.

Saeki, H., \& Tamaki, K. (2006). Thymus and activation regulated chemokine (TARC)/CCL17 and skin diseases. J. Dermato.l Sci. 43, 75-84.

Salcedo, R., Young, H. A., Ponce, M. L., Ward, J. M., Kleinman, H. K., Murphy, W. J., \&Oppenheim, J. J. (2001). Eotaxin (CCL11) induces in vivo angiogenic responses by human CCR3+ endothelial cells. J. Immunol. 166, 7571-7578.

Sallusto, F., Lanzavecchia, A., \& Mackay, C. R. (1998a). Chemokines and chemokine receptors in T-cell priming and Th1/Th2-mediated responses. Immunol. Today 19, 568-574.

Sallusto, F., Schaerli, P., Loetscher, P., Schaniel, C., Lenig, D., Mackay, C. R., Qin, S., \& Lanzavecchia, A. (1998b). Rapid and coordinated switch in chemokine receptor expression during dendritic cell maturation. Eur. J. Immunol. 28, 2760-2769.

Sallusto, F., \& Baggiolini, M. (2008). Chemokines and leukocyte traffic. Nat. Immunol. 9, 949952.

Sato, T., Komai, M., Iwase, M., Kobayashi, K., Tahara, H., Ohshima, E., Arai, H.,\& Miki, I. (2009). Inhibitory effect of the new orally active CCR4 antagonist K327 on CCR4+CD4+ T cell migration into the lung of mice with ovalbumin-induced lung allergic inflammation. Pharmacology 84, 171-182.

Sánchez-Sánchez, N., Riol-Blanco, L., \& Rodríguez-Fernández, J. L. (2006). The multiple personalities of the chemokine receptor CCR7 in dendritic cells. J. Immunol. 176, 5153-5159.

Scandella, E., Men, Y., Legler, D. F., Gillessen, S., Prikler, L., Ludewig, B.,\& Groettrup, M. (2004). CCL19/CCL21-triggered signal transduction and migration of dendritic cells requires prostaglandin E2. Blood 103, 1595-1601.

Schaniel, C., Sallusto, F., Ruedl, C., Sideras, P., Melchers, F., \& Rolink, A. G. (1999). Three chemokines with potential functions in T lymphocyte-independent and -dependent B lymphocyte stimulation. Eur. J. Immunol. 29, 2934-2947.

Sekiya, T., Tsunemi, Y., Miyamasu, M., Ohta, K., Morita, A., Saeki, H., Matsushima, K., Yoshie, O., Tsuchiya, N., Yamaguchi, M., et al. (2003). Variations in the human Th2specific chemokine TARC gene. Immunogenetics 54, 742-745.

Semmling, V., Lukacs-Kornek, V., Thaiss, C. A., Quast, T., Hochheiser, K., Panzer, U., Rossjohn, J., Perlmutter, P., Cao, J., Godfrey, D. I., et al. (2010). Alternative crosspriming through CCL17-CCR4-mediated attraction of CTLs toward NKT celllicensed DCs. Nat. Immunol. 11, 313-320.

Shimada, Y., Takehara, K., \& Sato, S. (2004). Both Th2 and Th1 chemokines (TARC/CCL17, MDC/CCL22, and Mig/CXCL9) are elevated in sera from patients with atopic dermatitis. J. Dermatol. Sci. 34, 201-208.

Shoji, N., Asano, K., Furuta, A., Hirano, K., \& Suzaki, H. (2011). Effect of histamine H1 receptor antagonists on TARC/CCL17 and MDC/CCL22 production from CD14+ cells induced by antigenic stimulation in vitro. Int. Arch. Allergy Immunol. 155, 38-51. 
Soumelis, V., Reche, P. A., Kanzler, H., Yuan, W., Edward, G., Homey, B., Gilliet, M., Ho, S., Antonenko, S., Lauerma, A., et al. (2002). Human epithelial cells trigger dendritic cell mediated allergic inflammation by producing TSLP. Nat. Immunol. 3, 673-680.

Sozzani, S., Allavena, P., D'Amico, G., Luini, W., Bianchi, G., Kataura, M., Imai, T., Yoshie, O., Bonecchi, R., \& Mantovani, A. (1998). Differential regulation of chemokine receptors during dendritic cell maturation: a model for their trafficking properties. J. Immunol. 161, 1083-1086.

Specht, S., Frank, J. K., Alferink, J., Dubben, B., Layland, L. E., Denece, G., Bain, O., Förster, I., Kirschning, C. J., Martin, C., et al. (2011). CCL17 Controls Mast Cells for the Defense against Filarial Larval Entry. J. Immunol. 186, 4845-4852.

Spergel, J. M., Mizoguchi, E., Brewer, J. P., Martin, T. R., Bhan, A. K., \& Geha, R. S. (1998). Epicutaneous sensitization with protein antigen induces localized allergic dermatitis and hyperresponsiveness to methacholine after single exposure to aerosolized antigen in mice. J. Clin. Invest. 101, 1614-1622.

Stutte, S., Quast, T., Gerbitzki, N., Savinko, T., Novak, N., Reifenberger, J., Homey, B., Kolanus, W., Alenius, H., \& Förster, I. (2010). Requirement of CCL17 for CCR7- and CXCR4-dependent migration of cutaneous dendritic cells. Proc. Natl. Acad. Sci. U.S.A. 107, 8736-8741.

Suárez-Fariñas, M., Tintle, S. J., Shemer, A., Chiricozzi, A., Nograles, K., Cardinale, I., Duan, S., Bowcock, A. M., Krueger, J. G., and Guttman-Yassky, E. (2011). Nonlesional atopic dermatitis skin is characterized by broad terminal differentiation defects and variable immune abnormalities. J. Allergy Clin. Immunol. 127, 954-64.e1-4.

Takeuchi, H., Yamamoto, Y., Kitano, H.,\& Enomoto, T. (2005). Changes in thymus- and activation-regulated chemokine (TARC) associated with allergen immunotherapy in patients with perennial allergic rhinitis. J. Investig. Allergo.l Clin. Immunol. 15, 172-176.

Terada, N., Nomura, T., Kim, W. J., Otsuka, Y., Takahashi, R., Kishi, H., Yamashita, T., Sugawara, N., Fukuda, S., Ikeda-Ito, T., et al. (2001). Expression of C-C chemokine TARC in human nasal mucosa and its regulation by cytokines. Clin. Exp. Allergy 31, 1923-1931.

Thelen, M.,\& Stein, J. V. (2008). How chemokines invite leukocytes to dance. Nat. Immunol. 9, 953-959.

Toda, M., Leung, D. Y. M., Molet, S., Boguniewicz, M., Taha, R., Christodoulopoulos, P., Fukuda, T., Elias, J. A., \& Hamid, Q. A. (2003). Polarized in vivo expression of IL-11 and IL-17 between acute and chronic skin lesions 5 . J. Allergy Clin. Immunol. 111, 875-881.

Tsuda, T., Tohyama, M., Yamasaki, K., Shirakata, Y., Yahata, Y., Tokumaru, S., Sayama, K., \& Hashimoto, K. (2003). Lack of evidence for TARC/CCL17 production by normal human keratinocytes in vitro. J. Dermatol. Sci. 31, 37-42.

Tsunemi, Y., Saeki, H., Nakamura, K., Nagakubo, D., Nakayama, T., Yoshie, O., Kagami, S., Shimazu, K., Kadono, T., Sugaya, M., et al. (2006). CCL17 transgenic mice show an enhanced Th2-type response to both allergic and non-allergic stimuli. Eur. J. Immunol. 36, 2116-2127. 
Uchida, T., Suto, H., Ra, C., Ogawa, H., Kobata, T., \& Okumura, K. (2002). Preferential expression of $\mathrm{T}(\mathrm{h}) 2$-type chemokine and its receptor in atopic dermatitis. Int. Immunol. 14, 1431-1438.

Vestergaard, C., Bang, K., Gesser, B., Yoneyama, H., Matsushima, K., \& Larsen, C. G. (2000). A Th2 chemokine, TARC, produced by keratinocytes may recruit CLA+CCR4+ lymphocytes into lesional atopic dermatitis skin. J. Invest. Dermatol. 115, 640-646.

Vestergaard, C., Kirstejn, N., Gesser, B., Mortensen, J. T., Matsushima, K., \& Larsen, C. G. (2001). IL-10 augments the IFN-gamma and TNF-alpha induced TARC production in HaCaT cells: a possible mechanism in the inflammatory reaction of atopic dermatitis. J. Dermatol. Sci. 26, 46-54.

Vestergaard, C., Yoneyama, H., Murai, M., Nakamura, K., Tamaki, K., Terashima, Y., Imai, T., Yoshie, O., Irimura, T., Mizutani, H., et al. (1999). Overproduction of Th2specific chemokines in NC/Nga mice exhibiting atopic dermatitis-like lesions. $J$. Clin. Invest. 104, 1097-1105.

Vijayanand, P., Durkin, K., Hartmann, G., Morjaria, J., Seumois, G., Staples, K. J., Hall, D., Bessant, C., Bartholomew, M., Howarth, P. H., et al. (2010). Chemokine receptor 4 plays a key role in $\mathrm{T}$ cell recruitment into the airways of asthmatic patients. $J$. Immunol. 184, 4568-4574.

Viola, A. \& Luster, A. D. (2008). Chemokines and their receptors: drug targets in immunity and inflammation. Annu. Rev. Pharmacol. Toxicol. 48, 171-197.

Wang, G., Savinko, T., Wolff, H., Dieu-Nosjean, M. C., Kemeny, L., Homey, B., Lauerma, A. I., \& Alenius, H. (2007). Repeated epicutaneous exposures to ovalbumin progressively induce atopic dermatitis-like skin lesions in mice. Clin. Exp. Allergy 37, 151-161.

Weber, C., Meiler, S., Döring, Y., Koch, M., Drechsler, M., Megens, R. T. A., Rowinska, Z., Bidzhekov, K., Fecher, C., Ribechini, E., et al. (2011). CCL17-expressing dendritic cells drive atherosclerosis by restraining regulatory $\mathrm{T}$ cell homeostasis in mice. $J$. Clin. Invest. 121, 2898-910.

Wirnsberger, G., Hebenstreit, D., Posselt, G., Horejs-Hoeck, J., \& Duschl, A. (2006). IL-4 induces expression of TARC/CCL17 via two STAT6 binding sites. Eur. J. Immunol. 36, 1882-1891.

Wollenberg, A., Wen, S.,\& Bieber, T. (1995). Langerhans cell phenotyping: a new tool for differential diagnosis of inflammatory skin diseases. Lancet 346, 1626-1627.

Wu, D. (2005). Signaling mechanisms for regulation of chemotaxis. Cell Res 15, 52-56.

Xiao, T., Fujita, H., Saeki, H., Mitsui, H., Sugaya, M., Tada, Y., Kakinuma, T., Torii, H., Nakamura, K., Asahina, A., et al. (2003). Thymus and activation-regulated chemokine (TARC/CCL17) produced by mouse epidermal Langerhans cells is upregulated by TNF-alpha and IL-4 and downregulated by IFN-gamma. Cytokine 23, 126-132.

Yang, Y.-M., Feng, A.-L., Zhou, C.-J., Liang, X.-H., Mao, H.-T., Deng, B.-P., Yan, S., Sun, J.-T., Du, L.-T., Liu, J., et al. (2011). Aberrant expression of chemokine receptor CCR4 in human gastric cancer contributes to tumor-induced immunosuppression. Cancer Sci , 1264-1271. 
Yawalkar, N., Uguccioni, M., Schärer, J., Braunwalder, J., Karlen, S., Dewald, B., Braathen, L. R., \& Baggiolini, M. (1999). Enhanced expression of eotaxin and CCR3 in atopic dermatitis. J. Invest. Dermatol. 113, 43-48.

Yoo, J., Omori, M., Gyarmati, D., Zhou, B., Aye, T., Brewer, A., Comeau, M. R., Campbell, D. J.,\& Ziegler, S. F. (2005). Spontaneous atopic dermatitis in mice expressing an inducible thymic stromal lymphopoietin transgene specifically in the skin. J. Exp. Med. 202, 541-549.

Yu, B., Koga, T., Urabe, K., Moroi, Y., Maeda, S., Yanagihara, Y., \& Furue, M. (2002). Differential regulation of thymus- and activation-regulated chemokine induced by IL-4, IL-13, TNF-alpha and IFN-gamma in human keratinocyte and fibroblast. J. Dermatol. Sci. 30, 29-36.

Zlotnik, A., \& Yoshie, O. (2000). Chemokines: a new classification system and their role in immunity. Immunity 12, 121-127. 


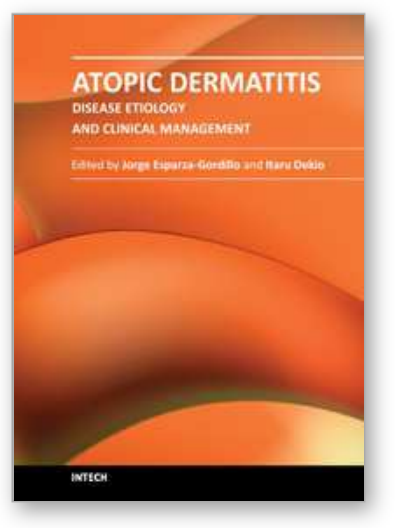

\author{
Atopic Dermatitis - Disease Etiology and Clinical Management \\ Edited by Dr. Jorge Esparza-Gordillo
}

ISBN 978-953-51-0110-9

Hard cover, 414 pages

Publisher InTech

Published online 22, February, 2012

Published in print edition February, 2012

Atopic Dermatitis is a common disease characterized by inflamed, itching and dry skin. This relapsing allergic disorder has complex etiology and shows a remarkably high clinical heterogeneity which complicates the diagnosis and clinical management. This book is divided into 4 sections. The first section (Disease Etiology) describes some of the physiological mechanisms underlying Atopic Dermatitis, including alterations in the immune system and the skin-barrier function. The important role of host-microorganism interactions on the pathophysiology of Atopic Dermatitis is discussed in the second section (Microorganisms in Atopic Dermatitis). An overview of the clinical diagnostic criteria and the disease management protocols commonly used is given in the third section (Diagnosis and Clinical Management). The last section (New Treatments) describes new therapeutic approaches that are not widely used but are currently being studied due to preliminary evidence showing a clinical benefit for Atopic Dermatitis.

\title{
How to reference
}

In order to correctly reference this scholarly work, feel free to copy and paste the following:

Susanne Stutte, Nancy Gerbitzki, Natalija Novak and Irmgard Förster (2012). Expression and Function of CCL17 in Atopic Dermatitis, Atopic Dermatitis - Disease Etiology and Clinical Management, Dr. Jorge EsparzaGordillo (Ed.), ISBN: 978-953-51-0110-9, InTech, Available from: http://www.intechopen.com/books/atopicdermatitis-disease-etiology-and-clinical-management/expression-and-function-of-ccl17-in-atopic-dermatitis

\section{INTECH}

open science | open minds

\section{InTech Europe}

University Campus STeP Ri

Slavka Krautzeka 83/A

51000 Rijeka, Croatia

Phone: +385 (51) 770447

Fax: +385 (51) 686166

www.intechopen.com

\section{InTech China}

Unit 405, Office Block, Hotel Equatorial Shanghai

No.65, Yan An Road (West), Shanghai, 200040, China

中国上海市延安西路65号上海国际贵都大饭店办公楼 405 单元

Phone: +86-21-62489820

Fax: $+86-21-62489821$ 
(C) 2012 The Author(s). Licensee IntechOpen. This is an open access article distributed under the terms of the Creative Commons Attribution 3.0 License, which permits unrestricted use, distribution, and reproduction in any medium, provided the original work is properly cited. 